\title{
OPTIMALISASI PERAN INTERNATIONAL CRIMINAL COURT DAN APLIKASI AKSI KEMANUSIAAN SEBAGAI INISIASI PENYELESAIAN KASUS ETNIS ROHINGYA
}

\author{
Ayub Torry Satriyo Kusumo \\ Fakultas Hukum Universitas Sebelas Maret Surakarta \\ E-mail: ayub.kusumo@gmail.com
}

\begin{abstract}
Rohingya is an ethnic in Myanmar which becomes victim of human rights violation by the unrecognition of the ethnic citizenship. They also undergo several treatments which lead to genocide trials. The government of Myanmar did not take any optimal action in order to bring this problem to an end. There are three action proposed in this writings to initiate a problem solving, i.e.: a case settlement with the act of International Criminal Court based on Rome Statute 1998; a humanitarian action as a step regarding the government failure in overcoming the humanitarian crisis on the ethnic of Rohingya; and an application of hu-man security concept in order to bring back the security of Rohingya people. Those actions can be carried out through the mechanism of international organization such as UN and its derivative bodies; or through the mechanism of regional bodies where Myanmar is one of the member, ASEAN.
\end{abstract}

Keywords : Rohingya ethnic, International Criminal Court, Humanitarian Action

\begin{abstract}
Abstrak
Etnis Rohingya merupakan salah satu etnis di Myanmar yang menjadi korban pelanggaran HAM berat yang berupa tidak diakuinya etnis tersebut sebagai warga negara Myanmar. Etnis tersebut juga mengalami perlakuan yang mengarah pada usaha-usaha genosida. Pemerintah Myanmar hingga saat ini tidak mengambil langkah yang optimal dalam menyelesaikan kasus ini. Terdapat tiga hal utama yang dapat dilakukan dalam menyelesaikan kasus Etnis Rohing-ya ini, antara lain penyelesaian kasus Rohingya melalui mekanisme International Criminal Court (ICC) berdasarkan Statuta Roma 1998; melakukan aksi kemanusiaan sebagai bentuk sikap atas kegagalan pemerintah Myanmar mengatasi krisis kemanusiaan terkait Etnis Ro-hingya, serta penerapan konsep human security sebagai usaha pengembalian keamanan et-nis Rohingya. Usaha-usaha tersebut dapat dilakukan oleh seluruh warga dunia, baik melalui organisasi internasional seperti PBB, atau melalui organisasi regional seperti ASEAN, sehingga permasalahan Etnis Rohingya tidak berkepanjangan dan menjadi masalah kemanusiaan yang lebih besar.
\end{abstract}

Kata kunci : Etnis Rohingya, International Criminal Court, Aksi Kemanusiaan

Pendahuluan

Etnis Rohingya telah mengalami pelanggaran Hak Asasi Manusia (HAM) sejak Pemerintahan Junta militer yang dikenal sebagai The State Peace and Development Council (SPDC) berkuasa di Myanmar, salah satu negara di Asia Tenggara. Salah satu bentuk pelanggaran HAM terhadap etnis Rohingya adalah tidak diakuinya etnis tersebut sebagai bagian dari masyarakat pribumi Myanmar. Dahulu Myanmar dikenal dengan nama Burma, namun pada tanggal 18 Juni 1989 nama
Burma diubah oleh Junta Militer menjadi Myanmar. Myanmar merupakan negara multi agama dengan jumlah penduduk mencapai sekitar 60 juta orang.

Tidak diakuinya etnis Rohingya berdasarkan pada Pasal 3 Burma Citizenship Law 1982 yang menyatakan bahwa, nationals such as the Kachin, Kayah, Karen, Chin, Burman, Mon, Rakhine or Shan and ethnic grous as have settled in any of territories included within the State as their permanent home from a periode anterior 
to 1185 B.E, 1823 A.D are Burma citizens. Etnis Rohingya hanya merupakan warga pendatang yang ditempatkan oleh penjajah Inggris dari Bangladesh. Hal itu juga diperkuat pada tanggal 21 Februari 1992 Menteri Luar Negeri Myanmar, U Ohn Gyaw menyatakan bahwa:

In actual fact, although there are 135 national races in Myanmar today, the socalled Rohingya people are not one of them. Historically, there has never been a "Rohingya" race in Myanmar...Since the first Anglo-Myanmar War in 1824, people of Muslim faith from the adjacent country illegally entered Myanmar Naing-Ngan, particularly Rakhine State. Being illegal immigrants they do not hold immigration papers like other nationals of the country. ${ }^{1}$

Berdasarkan pernyataan-pernyataan di atas, warga negara Myanmar haruslah berasal dari salah satu dari 135 etnis grup yang diakui oleh Konstitusi dan mereka yang nenek moyangnya telah berada di Burma sebelum tahun 1823. Undang-Undang ini bersifat diskriminasi karena Rohingya tidak diakui sebagai warga negara tetapi justru diberikan status sebagai imigran di tanah kelahirannya sendiri.

Menurut ketentuan Pasal 10 Konstitusi Myanmar 1948, "There shall be but one citizenship throughout the Union; that is to say, there shall be no citizenship of the unit as distinct from the citizenship of the Union", dari ketentuan tersebut sebenarnya orang-orang Rohingya ini masih dianggap sebagai warga negara Myanmar. ${ }^{2}$ Rohingya pernah diakui sekaligus menduduki jabatan penting di dalam pemerintahan Myanmar. Pada kisaran tahun 1948-1962, saat pemerintahan U Nu berkuasa di Myanmar, Sultan Mahmood, seseorang yang berasal dari etnis Rohingya, pernah diangkat menjadi sekretaris politik dalam pemerintahan $\mathrm{U}$ Nu dan kemudian diangkat menjadi Menteri Kesehatan Myanmar. Orang-orang Rohingya diperbolehkan melakukan pemungutan suara untuk mewakili hak-hak di Pyithu Hluttaw (Majelis Nasional) dan pemilihan umum diberbagai tingkat Pyithu (Nasional)

Utiyafina Mardhati Hazhin, 2013, Aspek Kedudukan Hukum Etnis Rohingya Menurut Hukum Pengungsi Interna- atau di tingkat Dewan. Namun status kewarganegaraan mereka diatur di bawah Konstitusi 1974 dan dinyatakan bukan sebagai salah satu etnis pribumi. Hal ini diperkuat lagi dengan Burma Citizenship Law 1982 di atas.

Banyak pendapat berbeda yang menjelaskan sejarah Etnis Rohingya. Rohingya berasal dari kata Rohan, nama kuno dari Arakan. Rohingya adalah nama kelompok etnis yang tinggal di negara bagian Arakan/Rakhine sejak abad ke $7 \mathrm{Ma}$ sehi. Nenek moyang Rohingya adalah berasal dari campuran Arab, Turki, Persia, Afghanistan, Bengali dan Indo-Mongoloid. Etnis Rohingya tersebut melakukan perkawinan sehingga meningkat prosentase kelahirannya. Populasi orang Rohingya saat ini sekitar 1.5 juta - 3 juta jiwa.

Berbagai bentuk tindak pelanggaran HAM terhadap etnis Rohingya antara lain tindakan genosida sejak 1978 dengan tujuan untuk mengusir keberadaan mereka dari wilayah Myanmar. Hak kebebasan untuk bergerak (freedom to movement) bagi orang-orang Rohingya dibatasi secara ketat dan sebagian besar dari mereka tidak diakui sebagai warga negara Myanmar, melainkan sebagai imigran ilegal. Pada tahun 1978, terjadi pula operasi militer masif, yang dikenal dengan nama Operasi Naga Min (Dragon King) untuk menghilangkan imigran ilegal, bahkan pada tahun 2012, sejak terjadinya konflik 10-28 Juni 2012 sedikitnya 650 warga etnis Rohingya tewas, sekitar 1200 warga dinyatakan hilang, dan 50 ribu warga kehilangan tempat tinggal.

Realitas tersebut menunjukan pembantaian Muslim Rohingya bukan hanya konflik sektarian semata, namun sudah mengarah pada genosida. Menurut data resmi pemerintah Myanmar, warga Muslim mencapai 5 persen dari 50 juta total penduduknya. Sebelum dan sesudah kemerdekaan Myanmar 1960, umat Islam tersebar di setiap kota. Akibat dari Myanmarisasi yang diterapkan Pemerintah Myanmar 1962, umat Islam hanya tersisa di tujuh kota Arakan, yaitu: Sittwe, Thandue, Kyaw Taw, Kyaw Pyu, Rathedang, Buthudang, dan Mangdow. Kasus etnis Rohingya telah menimbulkan kematian warga sipil, pemba-

sional (Studi Perlindungan Hukum Etnis Rohingya di Indonesia), Skripsi, Surakarta: FH UNS, hlm. 2

2 Ibid. 
karan rumah dan masjid, serta pemaksaan bagi mereka untuk meninggalkan tanah air. Warga Rohingya Muslim Myanmar telah mengalami pelanggaran HAM termasuk pembersihan etnis, pembunuhan, pemerkosaan, dan pemindahan paksa oleh pasukan keamanan Myanmar. Adapun pembahasan dalam artikel ini adalah penyelesaian konflik Etnis Rohingya yang dijabarkan menurut perspektif Hukum Humaniter Internasional melalui 3 (tiga) cara yaitu mengadili pelaku pelanggar HAM dengan mekanisme International Criminal Court (ICC), melakukan aksi kemanusiaan (Humanitarian Action) terhadap etnis Rohingya, dan mengembalikan keamanan di Myanmar dengan konsep Human Security.

\section{Pembahasan}

\section{Yurisdiksi ICC dalam Menangani Kasus Genosi- da Berdasarkan Statuta Roma 1998}

Sebelum tahun 1998, penegakan HAM secara internasional menggunakan peradilan AdHoc, contohnya peradilan HAM Ad-Hoc yang diinisiasi PBB adalah International Criminal Tribunal for Former Yugoslavia (ICTY) dan International Criminal Tribunal for Rwanda (ICTW). Hal tersebut menimbulkan keinginan dunia internasional untuk membentuk mekanisme internasional dalam penegakan HAM. Melalui suatu negosiasi, pada 17 Juli 1998, Perserikatan BangsaBangsa (PBB) membentuk Statuta Roma yang merupakan pengaturan dasar bagi berdirinya ICC. ${ }^{3}$ ICC merupakan lembaga independen dan permanen yaitu lembaga pemerintah dan nonpemerintah yang bebas dari pengendalian oleh pemanfaatan kelompok dan bebas dari kepentingan tertentu serta bersifat netral dan Permanen. ${ }^{4}$ Statuta Roma 17 Juli 1998 yang menjadi dasar pembentukan ICC secara eksplisit menegaskan bahwa pelaku kejahatan-kejahatan paling serius yang menyangkut perhatian masyarakat internasional secara keseluruhan tidak seharusnya berlalu tanpa dihukum dan penghukuman secara efektif harus dilakukan melalui tindakan-

Kevin Jon Heller, "A Sentence-Based Theory of Complementarity", Harvard International Law Journal, Vol. 53 No. 1, Tahun 2012, Massachusetts: Cambridge, hlm. 86

4 Sandra Van Thiel, "Trend in the Public Sector: Why Politicians Prefer Quasi- Austronomous Organizations", Vol. tindakan pada level nasional dan melalui peningkatan kerjasama internasional. ${ }^{5}$ Statuta Roma 1998 mengatur yurisdiksi ICC terhadap pelanggaran HAM berat. Adapun yurisdiksi tersebut sebagai berikut.

Pertama, Personal Jurisdiction. Personal jurisdiction merupakan yurisdiksi ICC berdasarkan subjek hukum yang dapat diadili. Pasal 25 Statuta Roma 1998 mengatur apabila terjadi pelanggaran terkait dengan kasus yang menjadi yurisdiksi material ICC (genosida, kejahatan terhadap kemanusiaan, kejahatan perang, dan agresi), maka yang bertanggung jawab atas perbuatan pelanggaran tersebut adalah yang sebagai berikut: (a) melakukan kejahatan baik secara individu, bersama-sama dengan orang lain atau melalui orang lain, tanpa memperhatikan apakah orang lain itu bertanggung jawab secara pidana atau tidak; (b) memerintahkan, menyuruh atau membujuk dilakukannya kejahatan yang pada kenyataannya terjadi atau diupayakan; (c) untuk tujuan memberi kemudahan dilakukannya kejahatan, bantuan, atau dengan cara lain membantu dalam pelaksanaan tindakan-tindakan yang di cobanya, termasuk memberikan cara-cara untuk melakukannya; (d) dengan cara lain yang memberikan kontribusi terhadap perbuatan atau perbuatan percobaan dari kejahatan itu oleh kelompok orang yang bertindak dengan tujuan yang telah jelas. Kontribusi itu akan bersifat disengaja dan akan merupakan salah satu dari: Dibuat dengan tujuan untuk kegiatan-kegiatan pidana atau tujuan pidana dari kelompok, di mana kegiatan itu atau tujuan-tujuan itu melibatkan perbuatan kejahatan dalam yurisdiksi pengadilan tersebut; atau Dibuat sepengetahuan dari kelompok untuk melakukan tindakan kejahatan; (e) berkaitan dengan kejahatan genosida/pemusnahan etnis, secara langsung ataupun melibatkan publik lain untuk melakukan genosida; (f) mencoba untuk melakukan kejahatan dengan mengambil tindakan yang memulai pelaksanaannya dengan cara-cara dari langkah yang sub-

16 No. 2, Tahun 2004, London: Sage Publications, hlm. 176.

5 Carsten Stahn, “One Step Forward, Two Steps Back?: Second Thoughts on a "Sentence-Based" Theory of Complementarity", Harvard International Law Journal, Vol. 53 No. 85, 2012, Massachusets: Cambridge, hlm. 184. 
stansial, tetapi kejahatan tersebut tidak terjadi karena keada-an-keadaan yang bebas dari maksud-maksud orang. Bagaimanapun juga, seseorang yang meninggalkan upaya untuk melakukan kejahatan atau dengan cara lain mencegah penyelesaian kejahatan tidak bertanggung jawab atas hukuman sesuai dengan Statuta ini untuk upaya-upaya untuk dilakukan kejahatan tersebut apa-bila orang tersebut secara sukarela dan sepenuhnya menyerah atas tujuan pidana.

Ketentuan Pasal 25 Statuta Roma 1998 menegaskan bahwa ICC memiliki yurisdiksi atas orang (natural persons). ICC, dengan demikian tidak berwenang untuk memeriksa dan mengadili legal persons, termasuk juga negara dan organisasi internasional. Adanya ketentuan personal jurisdiction ini, maka dapat menjadi salah satu fungsi untuk memutus rantai impunitas pelanggaran HAM berat. Hal ini berarti bahwa siapapun dapat dikenai sanksi pidana atas tindakan pelanggaran HAM berat, salah satunya genosida, meskipun individu yang melakukan tindakan genosida tersebut memiliki jabatan, kedudukan, atau bahkan memiliki imunitas atas jabatan pemerintahan yang dimilikinya.

Penulis berpendapat bahwa individu siapapun yang memang terbukti melakukan tindakan, baik dalam taraf sederhana seperti membujuk, memberi kemudahan, membantu dalam pelaksanaan tindakan yang dalam taraf mencoba, sampai pada taraf melakukan atau bahkan memerintahkan, dalam hal ini terkait yang mengarah pada pemusnahan atau pembunuhan suatu etnis (genosida), harus dikenai sanksi atas pelanggaran yang dilakukan tersebut. Pemimpin Junta Militer, jika dilihat terkait pelanggaran dalam kasus Etnis Rohingya, harus dikenakan pidana sesuai dengan ICC karena kejahatan terhadap Etnis Rohingya dilakukan melalui Operasi Militer Naga Min yang dilakukan berdasarkan perintah dari pemimpin Junta Militer. Hal ini dikenal sebagai prinsip command responsibility, yaitu bahwa seorang komandan meminta, mengetahui, membiarkan kejahatan yang dilakukan oleh bawahan secara sistematis dan massif, ${ }^{6}$ sehingga komandan bertanggung jawab penuh atas tindakan tersebut.

Kedua, Material Jurisdiction. Material jurisdiction merupakan yurisdiksi berdasarkan materi atau tindakan-tindakan yang dapat diadili menurut peraturan tersebut. Yurisdiksi material ICC adalah mengadili kejahatan HAM berat yang meliputi kejahatan kemanusiaan, genosida, kejahatan perang, dan agresi. ${ }^{7}$ Berdasarkan jenis kejahatan yang menjadi ruang lingkupnya, maka yurisdiksi ICC adalah pada kejahatan-kejahatan yang merupakan kejahatan paling serius (the most serious crime) diatur dalam Pasal 5-8 Statuta Roma 1998.

Statuta Roma 1998, yurisdiksi material di atur dalam Pasal 5-8. Pasal 5 menjelaskan bahwa ICC sebagai lembaga peradilan internasional hanya dapat mengadili pelanggaran yang oleh masyarakat internasional dianggap paling serius, yaitu terkait kasus kejahatan genosida, kejahatan terhadap kemanusiaan, kejahatan perang dan agresi. Ketentuan Pasal 6 Statuta Roma mengatur mengenai kualifikasi tindakan yang merupakan kejahatan genosida. Kualifikasi tersebut di atas juga memiliki persamaan dengan Pasal 4 ayat (2) International Criminal Tribunal for the Former Yugoslavia (ICTY) 1993, dan juga memiliki kesamaan dengan Pasal 2 ayat (2) International Criminal Tribunal for Rwanda (ICTR) 1994. Tindakan genosida yaitu meliputi salah satu dari tindakan berikut dengan maksud untuk menghancurkan seluruh atau sebagian kelompok bangsa, etnis, ras atau agama, seperti: membunuh anggota kelompok; menyebabkan penderitaan fisik atau mental yang berat terhadap anggota kelompok; dengan sengaja menimbulkan pada kelompok itu kondisi hidup yang menyebabkan kehancuran keseluruhan tentang fisik atau sebagian; memaksakan tindakan yang dimaksudkan untuk mencegah kelahiran di dalam kelompok; dengan paksa mengalihkan anak-anak dari suatu kelompok ke kelompok lain.

\footnotetext{
Noah Weisbord, "Prosecuting Aggression", Harvard International Law Journal, Vol. 49 No. 1, 2008, Massachusetts: Cambridge, hlm. 1.
}

Natsri Anshari, "Tangung Jawab Komando Menurut Hukum Internasional dan Hukum Nasional Indonesia", Jurnal Hukum Humaniter, Vol. 1 No. 1, Tahun 2005, Jakarta: Universitas Trisakti, hlm. 46. 
Berdasarkan pendapat yang dikemukakan oleh beberapa ahli, di antaranya Lemkin, Kegley, dan Wittkopf, Garner serta Goldstein, terdapat persamaan pendapat bahwa genosida menunjuk pada dua hal. Pertama, tindakan pemusnahan dan kedua, sasarannya adalah etnis/kelompok tertentu. Berdasarkan penjelasan mengenai beberapa pendapat mengenai kualifikasi genosida di atas, penulis berpendapat bahwa yang dimaksud genosida apabila salah satu tindakan tersebut dilakukan oleh individu, baik seorang ataupun berkelompok, yang mengarah pada tindakan penghancuran seluruh atau sebagian suatu bangsa, etnis, ras, atau agama. Selain itu, dalam beberapa pendapat tersebut tidak menjelaskan mengenai batasan jumlah korban yang ditimbulkan dari tindakan yang dinamakan genosida tersebut. Dalam Statuta Roma 1998 juga tidak mengatur mengenai hal tersebut, sehingga terdapat ketidakjelasan mengenai jumlah minimal korban yang diakibatkan oleh suatu tindakan dapat dikatakan genosida.

Ketiga, Temporal Jurisdiction. Temporal jurisdiction merupakan tindakan suatu lembaga yang dapat melaksanakan yurisdiksi untuk mengadili tindakan pelanggaran yang termasuk dalam kewenangan lembaga apabila lembaga tersebut telah dibentuk. Berdasarkan Pasal 11 Statuta Roma 1998, bahwa ICC hanya memiliki yurisdiksi atau suatu tindakan pelanggaran terhadap HAM berat dapat diadili setelah berlakunya Statuta Roma 1998, yaitu pada tanggal 1 Juli 2002, di mana pada saat itu, 60 negara telah meratifikasi Statuta tersebut ${ }^{8}$. Dalam hal ini, pelanggaran terhadap HAM berat setelah tanggal berlaku Statuta Roma 1998 inilah yang hanya dapat diadili.

Keempat, Territorial Jurisdiction. Territorial jurisdiction merupakan kewenangan suatu lembaga untuk melaksanakan yurisdiksi apabila masih dalam wilayah kewenangan lembaga tersebut. Mengenai yurisdiksi berdasarkan wilayah tempat dilakukannya tindakan pelanggaran, ada dua hal mengenai ketentuan berlakunya, yaitu meliputi negara peratifikasi Statuta dan

8 Ralph Henham dan Paul Behrens, 2007, The Criminal Law of Genocide: International, Comparative and Contextual Aspects, London: Ashgate Publishing Limited, hlm. 70. negara bukan peratifikasi Statuta. ${ }^{9}$ Dua hal terakhir dapat dijelaskan sebagai berikut. Pertama, Negara Peratifikasi Statuta Roma 1998. Pasal 126 Statuta Roma 1998, mengatur bahwa ICC berlaku pada hari pertama setelah dua bulan statuta diratifikasi oleh 60 negara dan diterima, disetujui, serta didaftarkan pada Sekretariat Jenderal PBB. Pelaksanaan yurisdiksi ICC, tentu secara otomatis berlaku bagi negara yang telah meratifikasi Statuta. Namun, yurisdiksi ICC tersebut dibatasi karena ICC bersifat komplementer, sebagaimana diatur dalam Pasal 1 Statuta Roma 1998. Hal ini berarti bahwa upaya peradilan dalam sistem hukum nasional suatu negara lebih diutamakan (exhaustion of local remedies). Apabila dalam sistem hukum nasional tidak dapat menyelesaikan, maka ICC dapat melaksanakan fungsi penuntutan sebagai bentuk upaya penyelesaian kasus tersebut. Kedua, negara bukan Peratifikasi Statuta Roma 1998. ICC dapat menangani kasus pelanggaran HAM berat yang dilakukan oleh negara bukan peratifikasi Statuta di wilayah negara anggota Statuta. Hal ini mencerminkan bahwa negara peratifikasi Statuta mendapatkan perlindungan terhadap pelanggaran HAM berat yang dilakukan di negara peratifikasi Statuta oleh negara yang bukan peratifikasi Statuta. ICC dapat melaksanakan yurisdiksi bagi negara pe-serta statuta terhadap kejahatan yang dilaku-kan di atas kapal atau pesawat yang telah dicatatkan, serta apabila terjadi kejahatan yang mengakibatkan korban bagi warga negara pada negara pihak peserta Statuta. Situasi tersebut, apabila terjadi pada negara yang bukan pihak peratifikasi statuta, maka harus mengajukan pernyataan yang diajukan ke kantor panitera bahwa negara tersebut menerima pelaksanaan yurisdiksi ICC.

Ketentuan Pasal 27 Statuta juga mengatur mengenai ketentuan terhadap negara bukan peratifikasi Statuta. ICC berlaku bagi setiap individu yang memang melakukan pelanggaran HAM berat, baik itu dari kepala negara, anggota pemerintahan, sampai kepada individu yang ti-

William Schabas, 2009, Customary Law or "Judge-Made" Law: Judicial Creativity at the UN Criminal Tribunals, Boston: Martinus Nijhoff Publishers, hlm. 79. 
dak dibebaskan dari tanggung jawab pidana sesuai dengan Statuta. Selain itu, dijelaskan pula bahwa individu dengan kekebalan atau peraturan yang melekat sebagai pemegang jabatan tertentu, baik sesuai dengan hukum nasional atau internasional, tidak akan menghambat pelaksanaan yurisdiksi dari ICC.

Berdasarkan Statuta Roma 1998, ICC memiliki yurisdiksi terhadap warga negara yang berasal dari non state parties dalam kondisikondisi sebagai berikut: kasus warga negara dari non state parties melakukan kejahatan di wilayah atau territorial negara anggota Statuta Roma atau negara yang sudah menerima yurisdiksi ICC berkaitan dengan kejahatan tersebut; dalam kasus negara non state parties sudah menyetujui untuk melaksanakan yurisdiksi berkaitan dengan kejahatan-kejahatan tertentu. ${ }^{10}$

\section{Penyelesaian Kasus Genosida Etnis Rohingya melalui mekanisme ICC}

Genosida berarti pembunuhan yang dilakukan secara sistematis dan terencana dengan maksud untuk menghancurkan atau memusnahkan seluruh atau sebagian kelompok bangsa, ras, kelompok etnis, dan kelompok agama.Terkait dengan kasus yang terjadi pada Etnis Rohingya, penulis berpendapat bahwa kasus yang terjadi tersebut merupakan suatu tindakan pelanggaran HAM berat genosida.

Berdasarkan isi Pasal 6 Statuta Roma 1998 dijelaskan bahwa hanya salah satu dari tindakan yang telah disebutkan di atas telah dapat digolongkan sebagai tindakan genosida, sehingga penulis berkeyakinan bahwa telah terjadi pembunuhan atau usaha menghilangkan keberadaan Etnis Rohingya yang dilakukan oleh pemerintah Myanmar. Selain itu, dalam Statuta Roma 1998 tidak menyebutkan jumlah korban minimal bahwa tindakan tersebut merupakan genosida. Hal ini berarti bahwa satu korban saja yang ditimbulkan dari tindakan yang sebagaimana dijelaskan dalam Pasal 6, dapat dikatakan sebagai genosida.

10 Sefriani, "Yurisdiksi ICC terhadap Negara non Anggota Statuta Roma 1998", Jurnal Hukum, Vol. 14 No. 2, Ta-

\section{Kewenangan ICC Menangani Kasus Genosida Etnis Rohingya \\ ICC dapat melaksanakan kewenangannya} atas suatu kasus jika negara yang mempunyai yurisdiksi atas kasus, sungguh-sungguh tidak mau (unwilling) atau tidak mampu (unable) untuk melakukan penyidikan atau penuntutan. ${ }^{11}$ Pasal 17 Statuta Roma 1998 mengatur bahwa ICC tidak dapat melaksanakan yurisdiksi berdasarkan beberapa alasan. Pertama, kasus tersebut sedang disidik dan dituntut oleh negara yang memiliki yurisdiksi atas kasus, kecuali negara tersebut sungguh-sungguh tidak mau (unwilling) atau tidak mampu (unable); kedua, kasus itu telah diselidiki oleh negara yang mempunyai yurisdiksi terhadapnya dan negara itu telah memutuskan tidak menuntut individu tersebut; ketiga, individu yang bersangkutan telah dihukum; keempat, kasus itu cukup bukti untuk membenarkan tindakan-tindakan lebih lanjut oleh pengadilan.

Ketentuan Pasal 17 ayat (2) Statuta Roma 1998 menjelaskan bahwa ICC dapat melaksanakan yurisdiksi apabila salah satu syaratnya sistem pengadilan nasional suatu negara unwilling. Ketentuan Pasal 17 ayat (3) Statuta Roma 1998 menjelaskan bahwa ICC akan mempertimbangkan indikator (unable) ketidakmampuan, baik itu ketidakmampuan secara menyeluruh atau kegagalan substansial, sehingga sistem peradilan nasional tidak dapat melaksanakan sendiri proses persidangan.

Berdasarkan penjelasan Pasal 17 Statuta Roma 1998, indikator mengenai unwilling atau unable pada dasarnya berlaku pada negara yang telah meratifikasi. Bagi negara yang belum meratifikasi, seperti pada negara Myanmar, maka dasar agar ICC dapat melaksanakan kewenangannya dapat dilihat dalam Pasal 12 Statuta Roma 1998. Pasal tersebut menjelaskan apabila suatu pelanggaran terjadi pada negara yang bukan pihak peratifikasi statuta, maka harus mengajukan pernyataan yang diajukan ke kantor panitera bahwa negara tersebut menerima pelaksanaan yurisdiksi ICC.

hun 2007, Yogyakarta: Universitas Islam Indonesia, hlm. 86.

11 William A. Schabas, op.cit, hlm. 68. 
Ketentuan Pasal 13 Statuta Roma 1998 juga dapat dijadikan landasan berlakunya ICC atas kasus Rohingya. Pasal 13 mengatur bahwa ICC dapat melaksanakan yurisdiksi penanganan terhadap pelanggaran HAM berat, apabila kasus tersebut diajukan oleh negara peserta Statuta, atas rekomendasi dari Dewan Keamanan Perserikatan Bangsa-Bangsa (DK PBB) sesuai dengan Bab VII Piagam PBB, dan atas inisiatif dari Penuntut ICC. Hal ini tidak jauh berbeda dengan Pasal 16 Statuta yang mengatur mengenai penundaan penuntutan yang juga didasarkan atas keputusan DK PBB, sehingga dalam hal ini keputusan DK PBB dapat digunakan untuk menyelesaikan kasus Rohingya dan dapat mempengaruhi keamanan dan perdamaian dunia.

Pada kasus genosida Etnis Rohingya, penulis berpendapat bahwa negara Myanmar memang menunda atau tidak berniat untuk menyelesaikan kasus tersebut, karena pada dasarnya Etnis Rohingya tidak diakui sebagi warga negara Myanmar. Tidak berjalannya sistem hukum nasional Myanmar menjadi salah satu bukti bahwa pemerintah Myanmar tidak mengusahakan tindakan penyelesaian terhadap kasus terkait Etnis Rohingya. Oleh karenanya, sebagaimana fungsi dari ICC untuk menyelesaikan kasus pelanggaran HAM berat, maka seharusnya ICC dapat segera menangani kasus tersebut melalui mekanisme keputusan DK PBB mengingat Myanmar bukanlah sebagai negara peratifikasi.

Indikator unwilling sebagaimana dijelaskan dalam Pasal 17 ayat (2) Statuta antara lain: Apabila proses hukum yang dilaksanakan justru dilakukan untuk melindungi pelaku dari pertanggungjawaban pidana; apabila terdapat penundaan yang berlarut-larut, dan apabila proses peradilan tidak dilaksanakan secara merdeka dan tidak memihak. Dalam kasus ini, maka pemerintah Myanmar cenderung pada indikator yang tercantum dalam huruf (b). Pemerintah Myanmar terkesan menunda penyelesaian kasus terkait etnis tersebut dengan alasan bahwa Etnis Rohingya bukan warga negara Myanmar meskipun etnis

12 Ibid, hlm. 207.

13 John Cerone, "Jurisdiction and The Power: The Intersection of Human Rights Law and The Law of Non-International Armed Conflict in an Extraterritorial Context", tersebut telah bermukim selama beberapa keturunan di Myanmar.

Indikator unable (ketidakmampuan), dijelaskan dalam Pasal 17 ayat (3) Statuta ${ }^{12}$ bahwa ICC akan mempertimbangkan apakah ketidakmampuan dikarenakan kegagalan secara substansial atau secara menyeluruh, atau dikarenakan ketidaktersediaan sistem peradilan nasional, sehingga negara tersebut tidak mampu untuk menghadirkan terdakwa atau bukti-bukti dan keterangan yang diperlukan, atau karena alasan lain sehingga tidak dapat melaksanakan sendiri proses persidangan. Terkait isi pasal tersebut, penulis mempunyai keyakinan Myanmar cenderung tidak dapat melaksanakan sendiri proses persidangan. Alasannya, karena kasus Etnis Rohingya tersebut bukanlah menjadi agenda utama pemerintah Myanmar. Pemerintah Myanmar akan cenderung menyelesaikan permasalahan yang mengedepankan warga negaranya terlebih dahulu.

Kondisi sistem peradilan nasional Myanmar yang tidak mampu berfungsi secara optimal dalam menyelesaikan kasus Etnis Rohingya sekaligus mengadili pelaku pelanggaran HAM berat terhadap Etnis Rohingya menjadi salah satu bukti pemenuhan indikator ketidakmampuan negara (unable). Hal ini memperkuat kedudukan ICC untuk ambil bagian dalam penyelesaian kasus Etnis Rohingya di Myanmar.

\section{Mengembangkan Humanitarian Action}

Hukum Internasional mempunyai prinsip non-intervensi dalam implementasinya. Namun prinsip tersebut hanya berlaku pada ranah hubungan internasional, jika berkaitan dengan HAM prinsip tersebut sudah mulai bergeser tidak menjadi kendala bagi dunia internasional untuk mengambil tindakan terhadap pelanggaran HAM maupun pelanggaran dalam konflik bersenjata. ${ }^{13}$ Salah satu tindakan internasional untuk penegakan HAM adalah Humanitarian ACtion. Humanitarian action menawarkan kepada aktor internasional seperti organisasi internasio-
Journal of International Law Forum, Vol. 40 No. 2, Tahun 2007, Jerussalem: Faculty of Law The Hebrew University of Jerussalem, hlm. 5 . 
nal dan non government organization (NGO) untuk mengatur krisis kemanusiaan yang sering terjadi berkaitan dengan konflik antar atau dalam negara. ${ }^{14}$ Konsep humanitarian action dibangun atas prinsip-prinsip dasar yang tercantum dalam Konvensi Jenewa IV, yaitu: prinsip kemanusiaan, netralitas, dan imparsialitas. ${ }^{15}$ Konvensi Jenewa I-IV mengatur hukum yang berlaku dalam perang guna meminimalisir penderitaan terhadap warga sipil. Konvensi Jenewa ini terdiri dari empat bagian dengan 3 protokol tambahan. Konvensi Jenewa I mengatur tentang perlindungan terhadap korban perang dan personil militer yang terluka pada saat perang bersenjata di darat, Konvensi Jenewa II mengatur perlindungan terhadap korban perang dan personil militer yang terluka saat perang bersenjata di laut, Konvensi Jenewa III mengatur mengenai perlakuan terhadap tawanan perang, dan Konvensi Jenewa IV mengenai perlindungan terhadap penduduk sipil.

Konvensi ini dibuat tidak hanya untuk mengatur hukum yang berlaku pada saat berperang, namun juga digunakan pasca konflik dan memberikan aturan main bahwa kedua belah pihak harus menghormati prinsip-prinsip dasar kemanusiaan. Konvensi ini memisahkan secara jelas bahwa keputusan untuk berperang tidak menghalangi kewajiban bagi para pihak yang bertikai untuk memberikan bantuan perlindungan terhadap warga sipil maupun mereka yang terluka. Prinsip-prinsip humanitarianism ini dirancang untuk mengarahkan pekerjaan badan-badan atau lembaga-lembaga yang bergerak dalam bidang kemanusiaan dan prinsip ini merupakan suatu standar kriteria minimum untuk penanganan bantuan agar lebih efektif. Adapun yang termasuk dalam prinsip-prinsip humanitarianism adalah kemanusiaan (humanity), netralitas (neutrality), dan imparsialitas (impartiality). ${ }^{16}$

14 Yeni Kusuma, "Peran UNICEF Atas Perlindungan Kekerasan Seksual terhadap Perempuan dalam Konflik di Republik Demokratik Kongo (2004-2008)", Jurnal Analisis Hubungan Internasional, Vol. 2 No. 3, Tahun 2007, Surabaya: Fakultas Hubungan Internasional Universitas Airlangga, hlm. 4.

15 Annisa Gita Srikandi, "Comprehensive Security dan Humanitarian Action", Jurnal Multiversa, Vol. 1 No. 2, Tahun 2010, Yogyakarta: Fakultas Ilmu Komunikasi dan Politik Universitas Gadjah Mada, hlm. 2.
Konsep 'kemanusiaan' merupakan komitmen paling dasar dari kerja kemanusiaan yang dilakukan oleh para aktor kemanusiaan dalam humanitarian action. Konsep kemanusiaan dalam Konvensi Jenewa menekankan usaha untuk menghilangkan penderitaan manusia yang terjadi akibat krisis atau bencana. Prinsip 'netralitas' mensyaratkan aksi kemanusiaan untuk tidak memihak salah satu pihak yang bertikai dalam konflik, sedangkan prinsip 'imparsialitas' mengacu pada kerja kemanusiaan yang dilakukan tanpa diskriminasi dengan tidak mempertimbangkan identitas kewarganegaraan, kesukuan, agama, jenis kelamin, atau pun ras, saat menolong mereka yang membutuhkan. ${ }^{17}$

Aksi kemanusiaan dilakukan apabila suatu negara dianggap gagal untuk mengatasi masalah-masalah kemanusiaan dan melindungi warga negaranya yang sebagian besar berhubungan dengan pelanggaran HAM. Apabila pelanggaran HAM tersebut berasal dari pemerintah yang berwenang atau dari adanya perang dan konflik internal, maka tanggung jawab negara dialihkan menjadi tanggung jawab internasional dengan bantuan dari pihak luar negara seperti yang tertera dalam konsep PBB, yaitu responsibility to protect. ${ }^{18}$

Menurut Jocelyn Kelly dalam Journal of Humanitarian Assistance, kewajiban merupakan suatu hal yang melatarbelakangi humanitarianism. ${ }^{19}$ Kewajiban moral diartikan sebagai suatu keharusan untuk melakukan sesuatu bagi mereka yang membutuhkan. Bantuan kemanusiaan diartikan sebagai kegiatan memberikan sesuatu kepada mereka yang tidak memiliki. Jadi kerja kemanusiaan ini dapat dilakukan untuk mengembalikan hak-hak dasar kemanusiaan yang sering kali hilang pada saat krisis kemanusiaan.

Definisi krisis kemanusiaan adalah krisis sosial yang terjadi dimana banyak korban jiwa

16 Jocelyn Kelly, "When NGOs beget NGOs: Practicing Responsible Proliferation", Journal of Humanitarian Assistance, Tahun 2009, hlm. 3, diakses pada web: http:// sites.tufts.edu/jha/archives/451, akses tanggal 10 Oktober 2013.

17 Annisa Gita Srikandi, op.cit., hlm. 3.

18 Yeni Kusuma, loc.cit.

19 Jocelyn Kell, op.cit., hlm. 2. 
meninggal dan menderita karena perang, penyakit menular, kelaparan, pengungsi dan bencana alam, ${ }^{20}$ sehingga konsep humanitarianism ini kemudian dilihat penerapannya dalam dua kondisi yaitu pada saat konflik dan bencana alam. Menurut penulis, dengan melihat semakin kompleksnya permasalahan Rohingnya, etnis tersebut membutuhkan aksi kemanusiaan yang antara lain dapat dilakukan oleh Association of South East Asian Nation (ASEAN) antara lain berupa pemberian bantuan bagi Rohingya, kerjasama antar negara ASEAN dalam menerima pengungsi Rohingya, dan rekomendasi kepada pemerintah Myanmar untuk menghormati HAM Rohingya serta memberikan status kewarganegaraannya. Dasar yang dapat digunakan untuk menggunakan kerjasama antar negara juga telah tertuang dalam Statuta Roma yaitu bagian preamble dari Statuta Roma 17 Juli 1998 yang menjadi dasar pembentukan ICC secara eksplisit menegaskan bahwa pelaku kejahatan-kejahatan paling serius yang menyangkut perhatian masyarakat internasional secara keseluruhan tidak seharusnya berlalu tanpa dihukum dan penghukuman secara efektif harus dilakukan melalui tindakan-tindakan pada level nasional dan melalui peningkatan kerjasama internasio-nal. Pada bagian lain dari preamble, Statuta Roma juga menyatakan bahwa "the States Parties to this Statute determined to put an end to impunity for the perpretator of these crimes and thus to contribute to the prevention of such crimes". ${ }^{21}$

\section{Human Security sebagai Sarana Pengembalian Keamanan Warga Rohingya}

Kerangka konsep human security pertama kali dikembangkan di United Nations Development Program (UNDP) pada Human Development Report 1994. Konsep keamanan (concept of security) ini terbentuk dari adanya potensi konflik antara negara-negara serta adanya ancaman terhadap perbatasan di suatu negara. Dewasa ini, keamanan kerja, adanya jaminan pendapatan, keamanan kesehatan, keamanan lingkungan, dan keamanan dari kejahatan yang merupakan bentuk kekhawatiran yang disikapi dan dijaga menurut konsep human security di seluruh dunia.

Definisi human security yang paling umum diambil dari Human Development Report tahun 1994, secara ringkas UNDP memberikan definisi human security dalam tiga aspek. Aspek yang pertama adalah aspek keamanan dari ancamanancaman kronis (chronic threats) seperti kelaparan, penyakit, dan represi. Aspek kedua, perlindungan dari gangguan yang tiba-tiba dan menyakitkan terhadap pola-pola kehidupan seharihari, baik di rumah, pekerjaan, maupun di komunitas, sedangkan aspek ketiga adalah kebebasan dari rasa takut, ancaman, atau bahaya.

Human security merupakan suatu upaya untuk mengembalikan konsep keamanan secara mendasar. Hal ini terutama karena konsep human security berfokus pada menjamin keamanan bagi individu, bukan negara. Konsep human security ini berkaitan langsung untuk mengurangi dan menghapus ketidakamanan yang mengganggu kehidupan manusia. Namun hal ini menjadi kontradiktif dengan konsep kemananan negara (concept of state security) yang hanya berfokus terutama pada menjaga integritas dan karakter kuat negara, sehingga negara hanya memiliki hubungan yang lebih pasif dengan keamanan masyarakat yang tinggal di negara tersebut atau mungkin tinggal di perbatasan negara. $\mathrm{Hu}$ man security ini dibentuk untuk menggeser fokus pikiran keamanan dari dominasi kedaulatan negara ke arah keamanan manusia yang mencakup masalah kesejahteraan sosial, perlindungan hakhak kelompok masyarakat, kelompok minoritas, anak-anak, wanita dari kekerasan fisik dan masalah-masalah sosial, ekonomi dan politik.

Keberadaan Etnis Rohingya jika dianalisis dengan aspek ketiga Human Security (kebebasan dari rasa takut, ancaman, atau bahaya), saat ini banyak Etnis Rohingya yang keluar dari Myanmar untuk mencari suaka atau menjadi pengungsi. Fenomena pengungsi adalah salah satu gejala yang signifikan dari adanya krisis ketidakamanan manusia karena rumah, barang-barang pribadi dan ikatan keluarga adalah bagian penting dari keamanan semua orang. Setiap negara yang di-

20 Annisa Gita Srikandi, loc.cit. 
datangi pengungsi tersebut tidak boleh memulangkan para pengungsi tersebut (non refoulement). ${ }^{22}$ Namun, non refoulement ini harus dibedakan dengan pengusiran (expulsion) atau deportasi (deportation) atau pemindahan secara paksa (forced removal). Pengusiran atau deportasi terjadi ketika warga negara asing dinyatakan bersalah karena melakukan tindakan yang bertentangan dengan kepentingan negara setempat, atau merupakan tersangka perbuatan pidana di suatu negara dan melarikan diri dari proses peradilan. Non refoulement hanya berlaku bagi pengungsi dan pencari suaka. ${ }^{23}$

Konsep ketidakamanan manusia (human insecurity) ini terkait erat dengan masalah nasib para pengungsi. Tentu saja hubungan ini terkait dengan pergerakan pengungsi dan berbagai bentuk lain dari pemindahan paksa seringkali menjadi indikator atas ketidakamanan manusia (human insecurity), karena pada kenyataannya, orang tidak akan meninggalkan rumah mereka dan mengungsi dari tempat asal mereka kecuali mereka menemui ancaman yang serius terhadap kehidupan, kebebasan, maupun kemanan mereka. Ada tujuh unsur yang membentuk konsep human security. Pertama, keamanan ekonomi (economic security) yaitu jaminan terhadap akses untuk mendapatkan kehidupan yang layak; kedua, keamanan pangan (food security) yaitu jaminan setiap individu untuk mendapatkan akses terhadap bahan pangan; ketiga, keamanan lingkungan (environmental security) jaminan kepada setiap individu untuk hidup di dalam lingkungan yang bersih dari polusi dan bahaya perubahan iklim; keempat, keamanan individu (personal security) jaminan keamanan bahwa setiap individu bebas dari intimidasi, kekerasan, kesewenangan, dan diskriminasi; kelima, keamanan komunitas (community security) yaitu jaminan bahwa individu bebas dari konflik komunal; dan keenam, keamanan politik (political security)

22 Ayub Torry SK, "Perlindungan Hak Asasi Manusia Pengungsi Internasional", Jurnal Hukum Yustisia, Edisi 83 Mei-Agustus 2011, Surakarta: Universitas Sebelas Maret, hlm. 5.

23 Sigit Riyanto, "Prinsip Non Refoulement dan Relevansinya dalam Sistem Hukum Internasional”, Jurnal Mimbar yaitu jaminan bahwa setiap individu dapat melaksanakan hak-hak politik mereka.

Masyarakat internasional melalui PBB hendaknya mendesak pemerintah Myanmar untuk mengembalikan keamanan di Myanmar, terutama bagi etnis Rohingya. Hal tersebut harus dilakukan mengingat salah satu tujuan dengan didirikannya PBB adalah untuk memelihara perdamaian dan keamanan internasional. ${ }^{24}$ Setidaknya ada tiga langkah yang dapat diambil oleh PBB dalam mengatasi konflik Rohingya. Pertama, Peace Making. Peace Making adalah tindakan untuk membawa para pihak yang bersengketa untuk saling sepakat khusus-nya secara damai, karena tujuan PBB untuk mencegah konflik dan menjaga perdamaian. Dalam hal ini DK PBB hanya memberikan rekomendasi atau usulan mengenai cara atau metode dalam mengatasi sengketa. Kedua, Peace Keeping. Peace Keeping adalah tindakan untuk mengerahkan kehadiran PBB dalam memelihara perdamaian dan kesepakatan para pihak yang berkepentingan misalnya dengan pengiriman polisi PBB, ataupun personel sipil. Ketiga, Peace Building. Peace Building adalah tindakan untuk mengidentifikasikan dan mendukung struktur-struktur yang ada guna memperkuat perdamaian untuk mencegah suatu konflik yang sudah didamaikan berubah kembali menjadi konflik, misalnya peran PBB dalam mengirimkan Aceh Monitoring Mission (AMM) pasca perundingan damai antara Pemerintah Republik Indonesia dan Gerakan Aceh Merdeka (GAM) .

\section{Penutup \\ Simpulan}

Etnis Rohingya merupakan salah satu etnis di Myanmar yang tidak diakui sebagai warga negara, sehingga tidak mendapatkan jaminan keamanan dan kemanusiaan dan bahkan menjadi korban pelanggaran HAM berat. Pemerintah Myanmar, di samping itu terkesan tidak berniat dan tidak mampu untuk menyelesaikan perma-

Hukum, Vol. 22 No. 3, Tahun 2010, Yogyakarta: Universitas Gadjah Mada, hlm. 435.

24 Justin S. Gruenberg, "Analysis of United Nations Security Council Resolutions: are All Countries Treated Equally?", Case Western Reserve Journal of International Law, Vol. 41 No. 3, Tahun 2009, Miami University, hlm. 469. 
salahan terkait etnis tersebut. Penulis berpendapat bahwa ada tiga langkah yang dapat dilakukan dalam menginisiasi penyelesaian kasus Etnis Rohingya ini, antara lain melalui optimalisasi peran ICC sesuai Statuta Roma 1998, pengembangan aksi kemanusiaan untuk etnis Rohingya, serta penerapan konsep Human Security untuk menjamin keamanan etnis Rohingya secara umum. Usaha-usaha tersebut dapat dilakukan melalui mekanisme organisasi internasional seperti PBB dan organisasi turunannya, atau melalui mekanisme organisasi regional seperti ASEAN di mana Myanmar adalah salah satu anggotanya.

\section{Daftar Pustaka}

Anshari, Natsri. "Tangung Jawab Komando Menurut Hukum Internasional dan Hukum Nasional Indonesia". Jurnal Hukum Humaniter. Vol. 1 No. 1. Tahun 2005. Jakarta: Universitas Trisakti;

Cerone, John. "Jurisdiction and The Power: The Intersection of Human Rights Law and The Law of Non-International Armed Conflict in an Extraterritorial Context". Journal of International Law Forum. Vol. 40 No. 2. Tahun 2007. Jerussalem: Faculty of Law The Hebrew University of Jerussalem;

Gruenberg, Justin S. "Analysis of United Nations Security Council Resolutions: are All Countries Treated Equally?" Case Western Reserve Journal of International Law. Vol. 41 No. 3. Tahun 2009. Miami University;

Hazhin, Utiyafina Mardhati. 2013. Aspek Kedudukan Hukum Etnis Rohingya Menurut Hukum Pengungsi Internasional (Studi Perlindungan Hukum Etnis Rohingya di Indonesia), Skripsi, Surakarta: FH UNS;

Heller, Kevin Jon. "A Sentence-Based Theory of Complementarity". Harvard International Law Journal. Vol. 53 No. 1. Tahun 2012. Massachusetts: Cambridge;

Henham, Ralph dan Paul Behrens. 2007. The Criminal Law of Genocide: International. Comparative and Contextual Aspects. London: Ashgate Publishing Limited;

Kelly, Jocelyn. "When NGOs beget NGOs: Practicing Responsible Proliferation". Journal of Humanitarian Assistance. Tahun 2009. hlm.3. diakses pada web: http://sites. tufts.edu/jha/archives/451. diakses pada tanggal 10 Oktober 2013;
Kusuma, Yeni. "Peran UNICEF Atas Perlindungan Kekerasan Seksual terhadap Perempuan dalam Konflik di Republik Demokratik Kongo (2004-2008)". Jurnal Analisis Hubungan Internasional. Vol. 2 No. 3. Tahun 2007. Surabaya: Fakultas Hubungan Internasional Universitas Airlangga;

Kusumo, Ayub Torry Satrio. "Perlindungan Hak Asasi Manusia Pengungsi Internasional". Jurnal Hukum Yustisia. Edisi 83 Mei-Agustus 2011. Surakarta: Universitas Sebelas Maret. hlm. 5.

Riyanto, Sigit. “Prinsip Non Refoulement dan Relevansinya dalam Sistem Hukum Internasional". Jurnal Mimbar Hukum. Vol. 22 No. 3. Tahun 2010. Yogyakarta: Universitas Gadjah Mada;

Sefriani. "Yurisdiksi ICC terhadap Negara non Anggota Statuta Roma 1998". Jurnal Hukum. Vol. 14 No. 2. Tahun 2007. Yogyakarta: Universitas Islam Indonesia;

Srikandi, Annisa Gita. "Comprehensive Security dan Humanitarian Action". Jurnal Multiversa. Vol. 1 No. 2. Tahun 2010. Yogyakarta: Fakultas Ilmu Komunikasi dan Politik Universitas Gadjah Mada;

Stahn, Carsten. "One Step Forward. Two Steps Back?: Second Thoughts on a "SentenceBased" Theory of Complementarity". Harvard International Law Journal. Vol. 53 No. 85. 2012. Massachusets: Cambridge;

Thiel, Sandra Van. Trend in the Public Sector: Why Politicians Prefer Quasi-Austronomous Organizations. Vol. 16 No. 2. 2004. London: Sage Publications;

Weisbord, Noah. "Prosecuting Aggression". Harvard International Law Journal. Vol. 49 No. 1. 2008. Massachusetts: Cambridge;

William Schabas. 2009. Customary Law or "Judge-Made" Law: Judicial Creativity at the UN Criminal Tribunals. Boston: Martinus Nijhoff Publishers. 